\title{
AKSELERASI GERAKAN DAKWAH MUHAMMADIYAH DI WILAYAH MINORITAS MUSLIM PAPUA BARAT
}

\author{
Ismail Suardi Wekke ${ }^{12}$, Barulazi ${ }^{1}$, Muhammad Rais ${ }^{1}$, Muhammad Idris ${ }^{3}$ \\ ${ }^{1}$ Sekolah Tinggi Agama Islam Negeri (STAIN) Sorong, Papua Barat \\ ${ }^{2}$ Universitas Muhammadiyah Sorong, Papua Barat \\ ${ }^{3}$ Universitas Negeri Malang
}

Tadarus Pemikiran Jaringan Intelektual Muda Muhammadiyah (JIMM)

Universitas Muhammadiyah Malang, 23-24 Mei 2018

\begin{abstract}
Muhammadiyah dikenal sebagai organisasi Islam yang memelopori gerakan pendidikan dan gerakan social modern. Saat ini pendidikan Muhammadiyah telah mengalami perkembangan yang pesat, tetapi masalah dan tantangan untuk terus dapat bersaing dan memberikan yang terbaik kepada masyarakat. Tujuan di dalam penelitian ini adalah untuk mengetahui bagaimana peran Muhammadiyah di dalam melakukan gerakan dakwah bil hal di bidang pendidikan dan sosial di Kota Sorong, Papua. Dengan menggunakan metode kualitatif dan teknik deep interview dan field research di lapangan, studi ini menemukan bahwa gerakan bil hal Muhammadiyah di Kota Sorong Papua telah memberikan dampak yang begitu signifikan terhadap masyarakat Kota Sorong, khususnya di bidang pendidikan mulai TK sampai perguruan tinggi. Sementara itu, untuk bidang sosial, Muhammadiyah di Kota Sorong mempunyai binaan panti asuhan putra dan putri. Namun demikian, secara pengelolaan tata kelola organisasi, Muhammadiyah Kota Sorong perlu memperkuat soliditas antar pimpinan daerah, optimalisasi majelis dan organisasi otonom sebagai basis kekuatan yang dapat mendukung maksimalisasi gerakan dakwah bil hal Muhammadiyah kedepan, khususnya di bidang pendidikan dan sosial.
\end{abstract}

Kata Kunci: Gerakan Dakwah, Muhammadiyah, Pendidikan, dan sosial.

\section{Pendahuluan}

Wacana tentang Muhammadiyah, seakan harus menghadirkan sosok KH. Ahmad Dahlan sebagai tokoh sentral pembaharu di bidang pendidikan yang tiada duanya. Tokoh yang kontroversial di zamannya ini, dihayati sebagai denyut napas masyarakatnya, yang senantiasa bergelut dengan kehidupan sehari-hari dibawah bayang-bayang kaum bangsawan, penjajah, tanpa dapat menolong kaum pinggiran. Masyarakatnya yang bergelut dengan kebodohan dan keterjajahan, baik dari segi pendidikan, ekonomi, agama, dan lain sebagainya. Umat Islamlah yang pada waktu itu yang sangat merasakan penderitaan akan arti keterbelakangan, jangankan bersaing dengan orang Belanda, bersaing dengan pribumi Kristen saja tidak dapat dimenangkannya.

Melihat masyarakatnya yang masih bergelut dengan keterbelakangan ekonomi, pendidikan, dan pemahaman agama, membuatnya prihatin, maka yang pertama kali dilakukannya adalah mengkaji surat al-Maun dan mengajarkannya kepada para santri. Para santri diajarkan untuk mengamalkan pesan yang tersurat dan tersirat dalam surat al-Maun. Teologi pembebasan surah 
al-maun ini kemudian diimplementasikan dalam gerak bil hal dengan memberikan santunan kepada warga di sekitarnya, kemudian dibentuklah Penolong Kesengsaraan Oemat (PKO) dalam spektrum yang lebih besar dan luas. Hal kedua yang menjadi perhatiannya adalah persaingan pendidikan, dengan inisiatif beliaulah sistem pendidikan agama dipadukan dengan sistem pendidikan umum. Banyak kalangan mencemoh atau bahkan menistakan apa yang dilakukannya tersebut. Kemudian yang ketiga, keadaan masyarakatnya yang masih melakukan tradisi-tradisi budaya dicampur dengan agama yang cenderung syirik, kurafat dan takhayul. Diilhami ketiga dimensi ini sehingga dibulatkan tekatnya untuk dibentuknya organisasi Muhammadiyah pada tahun 1912 Masehi.

Teologi pembesan surah al-Maun adalah bagian kecil dari ijtihad KH.Ahmad Dahlan. Sang Kyiai yang dulunya bernama Darwis. Dalam usia muda berangkat haji kemudian kembali lagi ke tanah suci untuk menuntut ilmu. Dengan bekal inilah kemudian yang dikembangkan di tanah air, sehingga tidak salah persentuhannya dengan pemikir Rasyid Ridha membuatnya semakin bersemangat diadakan pembaharuan di Indonesia, baik dari segi agama, sosial dan pendidikan. Tidak salah lagi kalau Muhammadiyah dengan para anggotanya tidak ragu-ragu membawa pesan KH.Ahmad Dahlan seantero Nusantara, tidak terkecuali di Sorong. Setiap anggota Muhammadiyah punya kewajiban prihatin dengan lingkungannya, kemudian berbuat sesuatu untuk lingkungannya, terutama dibidang pendidikan dan sosial. Hal inilah yang dapat dilihat di Kota Sorong, Muhammadiyah dibangun dari hasil solidaritas para anggotanya, kemudian dibangunnya Sekolah, Masjid, dan Panti Asuhan. Dalam penelitian ini, akan meneliti bagaimana perkembangan organisasi ini dalam menjawab tantangan zaman, menata organisasinya dengan berbagai dinamika internal dan eksternal yang semakin tinggi, terkadang mempertahankan jauh lebih sulit daripada membangun di awal. Dengan semangat beramar ma'ruf nahi munkar, apakah Muhammadiyah masih eksis dengan selogan ini dalam medan dakwah, pendidikan dan penyantunan. Ataukah tertinggal dikarenakan sikap orang-orangnya yang tidak berjalan di atas khittah pergerakan itu sendiri, mementingkan bangunan fisik dan melupakan yang lainnya.

\section{Muhammadiyah}

Dilihat dari banyak sisi, Muhammadiyah adalah organisasi keagamaan tertua di Indonesia. Sejak awal berdirinya tahun 1912 oleh KH. Ahmad Dahlan, Muhammadiyah menamakan dirinya sebagai gerakan tajdid (pembaharu). Dari segi orientasi keagamaan, Muhammadiyah pada dasarnya adalah gerakan Salafiyah dengan melakukan purifikasi atau pemurnian. Di bidang aqidah, berusaha membersihkan aqidah umat dari hal-hal yang bersifat khurafat dan takhayul yang bisa membawa kearah kemusyrikan. Di bidang ibadah, berusaha membersihkan ibadah umat dari hal-hal yang bersifat bid'ah.

Pemurnian kembali ajaran Islam ini berbentuk ijtihad dalam konteks historisitas kultural keagamaan, dengan menitik beratkan kepada amal usaha di bidang pendidikan, kesehatan, dan penyantunan anak yatim. Tujuannya menciptakan masyarakat mardlatillah, yang merupakan implementasi prinsip amar ma'ruf nahi mungkar. Dalam konteks penelitian ini, terutama di kota Sorong, Muhammadiyah dimulai keberadaannya dengan mendirikan sarana pendidikan dan panti asuhan sebagai wadah memulai pergerakannya disamping bentuk-bentuk pengajian umum.

\section{Dakwah Bil hal}

Muhammadiyah adalah gerakan Islam dan dakwah amar ma'ruf nahi munkar, berakidah Islam dan bersumber pada Al-Quran dan Sunnah, bercita-cita dan bekerja untuk terwujudnya 
masyarakat utama, adil makmur yang diridhai Allah SWT, untuk melaksanakan fungsi dan misi manusia sebagai hamba dan khalifah Allah di muka bumi ${ }^{1}$. Kaitannya dengan cita-cita di atas, tidak salah kalau Muhammadiyah di suatu wilayah atau daerah yang dibawanya adalah misi kemanusiaan dan amal.

Dakwah bil hal adalah dakwah dengan perbuatan nyata yang meliputi keteladanan. Misalnya dengan tindakan amal karya nyata, dari karya nyata tersebut hasilnya dapat dirasakan secara konkret oleh masyarakat sebagai objek dakwah. Dakwah bil hal dilakukan oleh Rasulullah, terbukti bahwa ketika pertama kali tiba di Madinah yang dilakukan Nabi adalah membangun masjid Al-Quba, mempersatukan kaum Anshar dan Muhajirin. Kedua hal itu adalah dakwah nyata yang dilakukan oleh Nabi yang dapat dikatakan sebagai dakwah bil hal. ${ }^{2}$

Dakwah bukanlah sekedar retorika, melainkan harus menjadi teladan tindakan sebagai dakwah pembangunan secara nyata. Ini dikarenakan makin meluas dan kompleksnya kebutuhan masyarakat yang perlu menerima dakwah. Jadi, dakwah harus menjadi "Komunitas non-Verbal" atau dakwah bil hal. Dakwah harus mengalami desentralisasi kegiatan. Ia tidak harus ada di masjid-masjid, pengajian-pengajian, tetapi juga harus berada di bawah, di permukiman kumuh, di rumah-rumah sakit, di teater-teater, di studio-studio film, musik, di kapal laut, kapal terbang, di pusat-pusat perdagangan, ketenagakerjaan, di pabrik-pabrik, di tempat-tempat gedung pencakar langit, di bank-bank, di pengadilan, dan sebagainya ${ }^{3}$. Spirit dakwah bil hal ternyata sangat terlihat dalam gerakan Muhammadiyah dimanapun dia didirikan. Ini juga yang akan diamati dalam penelitian ini, khususnya Muhammadiyah di Kota Sorong.

Gerakan melintasi zaman mengandung dua makna. Pertama, melewati, menjalani, menapaki, dan menghadapi masa atau keadaan sejak kelahirannya hingga usia ke-100 tahun. Kedua, menyeberangi atau melintas-batas yakni memasuki fase baru setelah usianya satu abad ke peralihan abad selanjutnya ${ }^{4}$. Gerakan Islam yang senantiasa istiqamah mengemban misi dakwah dan tajdid untuk mewujudkan peradaban yang utama. Gambaran perkembangan Muhammadiyah di daerah terutama di Kota Sorong tidak semudah yang dibayangkan semula. Menjaga aset-aset yang ada, dan dipertahankan serta ditingkatkan adalah tantangan tersendiri.

Di era reformasi muncul kecenderungan baru berbagai partai politik, kelompok kepentingan, dan gerakan keagamaan yang memengaruhi dinamika kehidupan nasional. Gerakan-gerakan baru tersebut tampil bukan sekedar memperjuangkan kepentingan sendiri, tetapi juga paham ajaran atau ideologinya, baik yang coraknya moderat maupun radikal. Kecenderungan baru tersebut merupakan konsekuensi logis dari era keterbukaan, yang semuanya mengklaim untuk membangun tatanan baru dalam kehidupan bangsa dan negara ke arah yang lebih baik. Namun tidak bisa diingkari bahwa keberadaan gerakan-gerakan tadi juga dapat melahirkan fragmentasi sosial baru yang tidak menutup kemungkinan menimbulkan konflik aliran dan kepentingan antar sesama komponen bangsa, termasuk di dalamnya konflik antar umat Islam sendiri. Kehadiran gerakan-gerakan baru tersebut, bagi Muhammadiyah tentu semakin mendorong semangat fastabiqul khairat untuk terus membangun kualitas umat dan bangsa. Namun, patut diakui pula

\footnotetext{
1 Haedar Nashir, Manhaj Gerakan Muhammadiyah, Ideologi, Khittah, dan Langkah, Suara Muhammadiyah, Yogyakarta, 2010, h.51

${ }^{2}$ Samsul Munir Amin, Ilmu Dakwah, Amzah, Jakarta, 2009, h.11.

${ }^{3}$ Nur Kholis Setiawan dan Djaka Soetapa, Meniti Kalam Kerukunan, BPK Gunung Mulia, Jakarta, 2010, h.170.

${ }^{4}$ H. Adjis Ahmad, Muhammadiyah dan Kaderisasi, dalam Refleksi Satu Abad Muhammadiyah, PWM B-Press, Yogyarkat, 2010, h.457
} 
bahwa perkembangan baru tersebut telah memberi peluang yang lebih terbuka bagi masuknya beragam paham atau kepentingan, baik yang sifatnya politik maupun keagamaan dan pemikiran yang tidak menguntungkan.

Di era reformasi muncul kecenderungan baru berbagai partai politik, kelompok kepentingan, dan gerakan keagamaan yang memengaruhi dinamika kehidupan nasional. Gerakan-gerakan baru tersebut tampil bukan sekedar memperjuangkan kepentingan sendiri, tetapi juga paham ajaran atau ideologinya, baik yang coraknya moderat maupun radikal. Kecenderungan baru tersebut merupakan konsekuensi logis dari era keterbukaan, yang semuanya mengklaim untuk membangun tatanan baru dalam kehidupan bangsa dan negara ke arah yang lebih baik. Namun tidak bisa diingkari bahwa keberadaan gerakan-gerakan tadi juga dapat melahirkan fragmentasi sosial baru yang tidak menutup kemungkinan menimbulkan konflik aliran dan kepentingan antar sesama komponen bangsa, termasuk di dalamnya konflik antar umat Islam sendiri ${ }^{5}$. Kehadiran gerakan-gerakan baru tersebut, bagi Muhammadiyah tentu semakin mendorong semangat fastabiqul khairat untuk terus membangun kualitas umat dan bangsa. Namun, patut diakui pula bahwa perkembangan baru tersebut telah memberi peluang yang lebih terbuka bagi masuknya beragam paham atau kepentingan, baik yang sifatnya politik maupun keagamaan dan pemikiran yang tidak menguntungkan.

\section{Gerakan Pendidikan dan Sosial}

Indonesia, di akhir abad ke-19 adalah sebuah negeri yang muram. Setelah runtuhnya kekuasaan monarkis di Nusantara, negeri ini terkoyak oleh kolonialisme, sebuah pengalaman kolektif sebagai bangsa yang menimbulkan trauma dan cedera historis. Pengalaman pahit sebagai bangsa di bawah penindasan kolonialisme itu dialami sebagian besar rakyat yang tenggelam dalam kemiskinan (struktural maupun kultural), kebodohan, dan keterbelakangan.

Dalam sektor ekonomi, kebijakan ekonomi liberal yang diberlakukan secara formal sejak tahun 1870 telah memberi kesempatan tidak hanya kepada pemerintah kolonial, melainkan juga kepada pihak asing untuk melakukan esksploitasi terhadap sumber-sumber ekonomi di seluruh Indonesia. Perkebunan dan pertambangan milik pemerintah maupun perusahaan swasta asing muncul di pulau Jawa maupun di pulau-pulau lain, berbeda dengan masa sebelumnya ketika esksploitasi itu hanya terkonsentrasi di pulau Jawa. Sementara itu, perluasan aktivitas ekonomi yang didasarkan pada sistem pasar dan penggunaan uang sebagai standar dalam setiap hubungan ekonomi, telah merangsang timbulnya komersialisasi dan monetisasi dalam kehidupan ekonomi masyarakat secara umum.

Sementara itu, dunia pendidikan juga banyak didominasi oleh kalangan Eropa dan elit feodal pribumi. Rakyat, yang mayoritas muslim, tidak banyak terakomodasi dalam sistem pendidikan moderen yang dikelola oleh pemerintah kolonial di Indonesia ${ }^{6}$. Dari gambaran aktivitas-aktivitas di atas, menginsipirasi KH. Ahmad Dahlan untuk memperbaiki keadaan lingkungan sekitarnya yang dimulai dari penolong kesengsaran umat, berdakwah secara langsung di lingkungannya serta menyelenggakan gerakan pendidikan.

\footnotetext{
${ }^{5}$ Ibid, h. 454

${ }^{6}$ Tim Penyusun dan Penerbit Profil Muhammadiyah 2010, Pimpinan Pusat Muhammadiyah, Yogyakarta, 2010, h.2.
} 
Muhammadiyah sebagai gerakan intelektual Islam kreatif yang mendesain perkembangan metakhir di zamannya, telah memposisikan planet bangsa waktu itu dalam poros pencerahan. Hal ini dibuktikan Ahmad Dahlan pada tanggal 8 Dzulhijjah $1330 \mathrm{H}$ bertepatan dengan 18 November 1912 M. Ahmad Dahlan menancapkan bendera penerangan di Kampung Kauman sebelah barat alun-alun Yokyakarta. Penerangan itu bernama Muhammadiyah? .

Muhammadiyah sejak awal berdirinya memiliki spirit pembebasan dari belenggu tradisionalisme dan konservatisme, yang menggugat kemapaman tradisi. Gerakan Muhammadiyah yang membawa spirit pencerahan di tengah kekolotan tradisi dan belengggu kolonialisme merupakan salah satu gerakan Islam. Hal ini untuk membantah tesis Huntington bahwa sebagian besar Negara-negara yang mayoritas muslim masih tercabik-cabik oleh kemiskinan, otoritarianisme, marjinalisasi perempuan, dan lemahnya supremasi hukum. Hal ini terbantahkan, dengan berdirinya sekolah-sekolah dan panti-panti asuhan yang dikelola oleh Muhammadiyah yang mengedepankan spirit pendidikan dan menolong masyarakat yang tidak mampu yang ada di sekitarnya, dimanapun organisasi ini berada. Hal ini dapat kita lihat dalam perjalanannya termasuk di Kota Sorong.

\section{Metode}

Metode yang diguanakan di dalam penelitian ini adalah kualitatif eksploratif, yaitu metode yang digunakan untuk mendapatkan gambaran yang objektif dengan metode "bola salju", yaitu bertanya kepada satu orang kemudian diteruskan kepada orang lain, sampai diperoleh informasi yang lengkap dari masalah yang diteliti. Sumber informasi studi adalah Tokoh Masyarakat internal Muhammadiyah, sesepuh dan penasehat Muhammadiyah, Pimpinan Daerah Muhammadiyah kota Sorong beserta pengurus serta anggota Muhammadiyah yang ikut menangani amal uasaha Muhammadiyah kota Sorong dan tokoh masyarakat lainnya. Sedangkan teknik pengumpulan datanya menggunakan wawancara, observasi, dan dokumentasi.

\section{Hasil dan Pembahasan}

\section{Gerakan Dakwah melalui pendidikan di Kota Sorong}

Kata Plato, pendidikan bukan sekedar mengisi bejana dengan air, tetapi pendidikan adalah menyalakan api dalam kegelapan. Kehidupan tanpa pendidikan seperti halnya agama tanpa ilmu, dan mungkin juga seperti peradaban tanpa buku ${ }^{8}$. Di Indonesia kesadaran akan pentingnya pendidikan dan pengilmuwan masyarakat diawali, salah satunya adalah, oleh Muhammadiyah yang kini gerak dalam lintasannya yang mencapai sampai satu abad. Dalam konteks sejarah, dengan kepeloporannya di bidang pendidikan, Muhammadiyah telah memberikan sumbangan berharga bagi bangsa ini yakni melahirkan generasi bangsa ini yakni melahirkan bangsa yang cerdas iman, kepribadian, dan alam pikirannya serta mampu menghadapi tantangan dan permasalahan kehidupan diberbagai ranah. Masyarakat luas mengenal dan mengidentifikasikan Muhammadiyah sebagai gerakan pendidikan.

Dilingkungan Muhammadiyah saat ini gerakan pendidikan menjadi salah satu usaha dalam bentuk amal usaha di bidang pendidikan. Dalam Anggaran Rumah Tangga Muhammadiyah tahun 2005, yang berkaitan dengan usaha di bidang pendidikan ialah (1) Meningkatkan harkat,

\footnotetext{
${ }^{7}$ Subhan Mas, Muhammadiyah Pintu Gerbang Protestanisme Islam, Al-Hikmah, Mojokerto, 2005, h. 33.

${ }^{8}$ Tim penyusun dan penerbitan profil Muhammadiyah 2010, PP Muhammadiyah, Yogyakarta, 2005, h.370.
} 
martabat, dan kualitas sumberdaya manusia agar berkemampuan tinggi serta berakhlaq mulia; dan (2) memajukan dan memperbaharui pendidikan dan kebudayaan, mengembangkan ilmu pengetahuan, teknologi, dan seni, serta meningkatkan penelitian ${ }^{9}$.

\section{Tantangan Muhammadiyah dalam dakwah di bidang pendidikan di Kota Sorong}

Lembaga pendidikan yang dikelola Muhammadiyah di Kota Sorong, dari mulai Taman Kanakkanak sampai ke Perguruan Tinggi diantaranya adalah Taman Kanak-Kanak Aisyiyah Bustanul Athfal 1, 2, dan 3, SD Muhammadiyah 1 dan 2, SMP Muhammadiyah, MTs. Muhammadiyah 1, SMA Muhammadiyah Al Amin, Madrasah Aliyah Muhammadiyah 2, dan Sekolah Tinggi Ilmu Administrasi (STIA) Al Amin. Sementara untuk di bidang sosial terdiri dari Panti Asuhan Putra dan Putri yang ada di Kota Sorong.

TK Aisyah I sebagaimana diketahui telah dilakukan tukar guling dengan pemerintah daerah yaitu tanah di Rufei. Konflik internal yang ditinggalkan oleh pengurus Muhammadiyah priode lalu meninggalkan kesan menyeluruh tentang masa depan TK ini kedepan. Pertama, organisasi tidak dapat menyelesaikan permasalahan mereka secara baik antara pengajar dengan lembaga. Kedua, dikembalikannya citra TK Aisyiah 1 seperti sediakala yaitu sebagai TK pavorit. Ketiga, wujud tanah TK Aisyiah I sudah tidak ada. Sehingga dari semua permasalahan ini, tugas pengurus Muhammadiyah menyelesaikan keberadaan TK ke depannya.

Tidak adanya satupun guru TK ABA II yang PNS merupakan tantangan tersendiri bagi kepala sekolah TK ABA II, bagaimana caranya untuk mencari honor bagi guru-guru di TK ABA II, 2. Lahan yang begitu sempit sehingga sulit untuk mengembangkan potensi yang dimiliki anak didik. Kurangnya perhatian dari yayasan khususnya PDM kota Sorong tentang perkembangan TK ABA II, selama ini berjalan sendiri tanpa bimbingan dan arahan dari PDM, TK ABA II mengharapkan adanya kunjungan dari PDM kota Sorong minimal 3 bulan sekali.

Dengan semakin banyaknya TK di kota Sorong tentu merupakan tantangan tersendiri bagi TK ABA II, baik dari segi sarana maupun prasarana, tapi selama ini TK ABA II masih bisa bersaing dengan TK-TK lain di kota Sorong, namun untuk kedepannya tentu mengharapkan perhatian dari yayasan dalam hal ini PDM kota Sorong.

Tenaga pendidik yang begronnya bukan dari guru, sehingga tidak menguasai tentang anak-anak dan masih sulit untuk menyesuaikan diri dengan anak didiknya. Dulu dikenal dengan SPG, tapi sekarang kebanyakkan guru dari SMA masuk PGSD, sehingga kurang menguasai karakter anak didiknya. Untuk kedepannya perlu untuk meningkatkan SDM pendidiknya.

Persaingan antar sekoalah semakin ketat dengan semakin banyaknya sekolah swasta maupun sekolah pemerintah, baik prestasi, kompetisi, sarana, dan prasarana.

Kurangnya perhatian dari yayasan khusunya PDM kota Sorong merupakan salah satu tantangan bagi SD Muhammadiyah 2 untuk berkembang, kemudian ditambah dengan malas taunya orang tua murid dengan pendidikan anaknya di sekolah merupakan tantangan tersendiri bagi para guru dalam mendidik dan membina anak-anak di sekolah, orang tua menyerahkan sepenuhnya pendidikan anak-anaknya disekolah. Sementara tantangan dari luar adalah persaingan dengan Sekolah lain baik swasta maupun Negeri.

\footnotetext{
${ }^{9}$ Adi Asmara, Sejarah dan Realita Pendidikan Muhammadiyah, dalam buku Refleksi Satu Abad Muhammadiyah, Pustaka Offset, Yogyakarta, 2010, h.624.
} 
Mutu guru dan fasilitas sekolah serta sarana dan prasarana sekolah yang baik. Ruang kelas dan kelengkapan alat-alat peraga dan laboratorium. Semua terintegrasi dalam satu system yang menyeluh. Muhammadiyah yang dibawahi majelis pendidikan dasar dan menengah, harus dapat menyatukan para pengajar agar tunduk pada aturan Muhammadiyah dan standar mutu yang diberikan oleh Departemen Pendidikan setempat. Dengan demikian, ada kesatuan gerak dalam penyelenggaraan pendidikan. Dampaknya, persekolahan ini semakin baik citranya dari dalam persekolahan itu sendiri.

Persaingan dengan sekolah Pemerintah yang membebaskan SPP, dan kecenderungan para orang tua yang memilih anaknya di sekolah Negeri. Memenangkan persaingan tidak harus mengorbankan mutu dan kualitas sekolah. Letak sekolah ini sangat strategis di jalan poros kota, sehingga seharusnyalah tantangan itu dijawab dengan melahirkan anak didik dengan baik. Para orangtua tidak segan-segan menyekolahkan anaknya jika sekolah ini dapat bersaing dalam penjaminan mutu lulusannya. Tinggal bagaimana masyarakat diyakinkan dengan kerja keras para pendidiknya.

Seluruh keperluan sekolah diurus oleh kepala sekolah, mulai dari gedung sampai keperalatan yang dibutuhkan, sementara Pimpinan Daerah Muhammadiyah dibawa Majelis Pendidikan Dasar dan Menengah kota Sorong kurang perhatian. Keluhan ini bisa dijawab dengan hasil yang dicapai sekarang dengan ditempatinya gedung baru yang megah. Dahulu MTs dengan kepengurusan PDM lama, semua terbengkalai, sekarang harapannya kepada pengurusan PDM baru memasuki satu tahun usianya dapat berbenah, sehingga segala permasalah internal dapat diselesaikan.

Hampir sebagian besar orang-orang Muhammadiyah enggan menyekolahkan anak-anak di MTs Muhammadiyah. Ini sebuah tantangan, ketidakpercayaan berimbas pada keengganan masyarakat umum pada sekolah ini. Harapan persekolahan Muhammadiyah dapat maju masih jauh bila tanpa dukungan warga Muhammadiyah. Selama ini MTs Muhammadiyah cuma sekedar pelarian, anak mereka tidak diterima di sekolah lain. Dengan fasilitas gedung baru sejak tahun 2010, ada harapan dan semangat baru, yaitu dukungan dari warga Muhammadiyah. Bukan cuma sekedar pelarian, tetapi ada kepercayaan bahwa persekolahan ini punya nilai tambah dan dipercaya para orangtua, MTs ini punya daya saing dengan fasilitas dan guru-gurunya.

Persaingan antar sekolah, terutama sekolah negeri yang membebaskan SPP. Tantangan ini terjawab jika persekolahan ini memberikan nilai tambah pada anak didiknya. Sekolah yang baik dan bermutu tidak takut akan pembebasan SPP oleh sekolah lain, tapi bila mutu semakin baik, tidak menutup kemungkinan persekolahan ini jadi rebutan para orangtua untuk menyekolahkan anak-anaknya.

Warga Muhammadiyah cuma mendukung dengan lisan saja, tetapi realisasi dilapangan tidak ada. Buktinya tidak ada satupun anak warga Muhammadiyah yang mau disekolahkan di SMA Muhammadiyah ini. Bahkan ada guru yang mengajar di sini tapi anaknya di sekolahkan di tempat lain. Pihak sekolah dituntut untuk mengembangkan sekolah dengan memperbanyak murid, tapi tidak di dukung oleh warga Muhammaiyah untuk menyekolahkan anak-anaknya di sini. Ditambah lagi dengan tidak adanya sistim atau kerja sama yang baik antar jenjang sekolah muhammadiyah. Kalau diyayasan lain ada sistem yang mengharuskan keja sama antar jenjang pedidikannya, kalau sekolah di TK yayasan harus juga masuk di SD yayasan tersebut, begitu seterusnya, makanya yayasan yang lain itu bisa ber kembang.Tantangan dari luar; Persaingan antar sekolah, baik swasta maupun negeri. 
Tantangan Internal dalam perguruan tinggi adalah bagaimana menyatukan persepsi terhadap pengembangan pendidikan Muhammadiyah kedepan, Sumber dana tetap dari yayasan tidak pasti, Banyak yang bekecimpung sebagai sampingan/ tidak fokus, Aktualisasi kedisiplinan waktu. Sedangkan untuk tantangan External pemerintah masih ada diskriminasi pemberdayaan PT Negeri dengan PT Swasta, Umat Islam belum menyamakan persepsi tentang lembaga pendidikan Islam, untuk mengubah persepsi masyarakat menganggap PT. Negeri lebih hebat di banding dengan PT Swasta.

\section{Tantangan Muhammadiyah dalam Dakwah di Bidang Sosial di Kota Sorong}

Gambaran terburuk panti asuhan putra pada tahun 2012 yaitu anak asuh tidak ada. Banyak beberapa faktor hal ini terjadi, pertama, bangunan lama panti ini sudah terkesan terbengkalai sejak badan jalan lebih tinggi dari bangunan panti itu sendiri. Kedua, pengasuh yang lebih professional tidak ada. Ketiga, batalnya rencana awal dimana panti ini akan didirikan pondok pesantren modern. Keempat, kurangnya minat anak asuh masuk ke panti ini. Sehingga gambaran-gambaran secara internal mempengaruhi kinerja panti yang seharusnya lebih fokus kepada anak didik tidak berjalan. Kepengurusan Pimpinan Muhammadiyah periode 2005-2010 yang tidak mampu membangun kebersamaan bahkan cenderung menimbulkan permasalahan baru dikalangan pengasuh. Dampaknya, panti ini tidak terurus dengan baik. Disatu sisi bangunannya sudah harus dibenahi, disisi lain anak asuh pada kabur.

Tantangan yang di hadapi panti asuhan adalah pembinaan mental anak-anak asuh, ada empat yang yang di haramkan bagi anak asuh yaitu: meninggalkan shalat, mencuri, pacaran, dan memiliki HP, kalau empat hal ini sampai di langgar oleh anak asuh maka terancam akan di keluarkan dari panti. Faktor lain yang harus dibenahi oleh Panti milik Muhammadiyah, tenaga pendidik di dalam panti yang selama ini sering berganti-ganti, bahkan ada kesan sulit mencari figur yang cocok menangani anak panti yang ideal. Panti bukan sekedar penampungan anak-anak yang dianggap tidak mampu. Tapi sarana mendidik mereka dari segi nilai agama dan moral yang baik. Sulitnya menjadi anak asuh terutama anak perempuan adalah tantangan terberat. Kejadiankejadian masa lalu tidak harus terulang, sehingga menyimpan trauma-trauma sosial yang dapat muncul kembali. Panti asuhan diharapkan rumah singgah yang baik bagi para anak yang membutuhkan uluran tangan untuk ditolong, serta saluran amal bagi para dermawan.

\section{Akselerasi Gerakan Muhammadiyah Kontemporer}

Taman kanak-kanak di Kota Sorong menciut dari 12 menjadi tinggal 3 sekolahan. Ini dikarenakan sebagian besar TK itu berada di wilayah Kabupaten Sorong. Dari segi manajerial juga rupanya mengalami penurunan, ini ditandai dengan berlarut-larutnya konflik internal di TK Aisyiah Bustanul Athfal 1 peninggalan pengurus Muhammadiyah lama, kemudian dilakukannya tukar guling buntut dari konflik itu. Tidak adanya pengembangan secara kuantitas maupun kualitas di taman kanak-kanak yang dikelola Muhammadiyah ditengah menjamurnya TK di Kota Sorong. Bukan tidak mungkin TK yang dikelola Muhammadiyah tertinggal dari TK yang baru berdiri, bila tidak berbenah dari sekarang.

Dalam perkembangan kekinian, TK ABA 1 akan mulai beroperasi kembali tahun ini, sementara TK ABA 2 pada tahun ajaran 2011/2012 ini memiliki 86 orang anak murid dan 8 orang tenaga guru. Semetara TK ABA 3 memiliki 108 orang murid, dan 7 Orang guru. Sedangkan, sekolah Dasar Muhammadiyah mengalami penambahan sekolah dalam kurun 27 tahun dari awal berdirinya tahun 1976 hingga 2003. Dari kurun waktu yang cukup lama itu, ternyata 
Muhammadiyah mengalami perlambatan dalam penambahan sekolah di Kota Sorong. Ini dimungkinkan, karena tidak adanya Sumber Daya Manusia yang memikirkan penambahan itu dan yang nanti pendidiknya. Lemahnya kepemimpinan ketua yang menjabat untuk menggerakkan majelis-mejalis dibawahnya. Kurangnya sokongan dari para simpatisan Muhammadiyah untuk memberikan masukan kepada organisasi. Namun kedua persekolah itu dalam jumlah siswa tidak ada masalah mengingat SD Muhammadiyah 1 sudah dikenal dan SD Muhammadiyah 2 letaknya strategis tepatnya di jalan protokol yaitu di jalan Basuki Rahmat km.10 Remu.Dalam perkembangan terkini SD Muhammadiyah 1 memiliki 401 orang murid, 22 orang guru, dan sudah terakreditasi A. Sementara SD Muhammadiyah 2 kota Sorong dalam perkembangan terkini memiliki 353 orang murid, 19 orang guru, dan sudah terakreditasi B.

SMP Muhammadiyah mengalami perkembangan cukup baik, namun dari segi jumlah sekolah tidak ada penambahan. Sejak SMP ini ditempatinya gedung baru di Km.10 Jl. Basuki Rahmat yang letaknya sangat strategis. Gedung yang refresentatif dua lantai, dengan halaman yang luas, bersebelahan dengan SD Muhammadiyah 2. Jumlah muridnya cukup menjajikan dengan kelengkapan sekolah dan guru yang ada. Dalam perkembangan terkini SMP Muhammadiyah terdapat 300 orang murid, 23 orang guru, dan sudah di akreditasi A. Sementara MTs Muhammadiyah 1 tidak mau kalah, menempati gedung baru yang letaknya di jalan Pendidikan, kini dapat bersekolah pagi hari. MTs tidak diandalkannya anak panti bersekolah di MTs ini, melainkan banyak datang dari berbagai lulusan SD di kota Sorong. Gedungnya juga mentereng berlantai dua dengan guru-guru cukup lengkap.Dalam perkembangan terkini MTs Muhammadiyah 1 memiliki 201 orang murid, 17 orang guru, dan sudah terakreditasi B.

Muhammadiyah masih perlu berbenah menata sekolah menengah atasnya. Pengelolaan sekolah ini sejak awal berdirinya sampai sekarang dari segi jumlah murid tidak terlalu menjanjikan. Sekolah ini telah ditempatinya gedung SMP yang lama, dengan jam mengajar pagi hari. Namun persekolahan ini tertinggal dalam hal penggalangan murid. Ini dikarenakan sekolah ini terlanjur tidak dilirik di tengah maraknya persekolahan setingkat SMA yang lebih menjanjikan bahkan dari pilihan-pilihan seperti kejuruan. Dalam perkembangan terkini SMA Muhammadiyah terdapat 16 orang guru dan 120 orang murid, dan masih akreditasi C.

Pengelolaan perguruan tinggi akan dilihat kedepannya sejak dibawah pangkuan Muhammadiyah tidak resmi 2006, secara resmi versi Muhammadiyah sejak April 2012. Muhammadiyah dengan sendirinya mendapatkan gedung, staf, dosen, dan mahasiswa, tinggal bagaimana dapat menata perguruan ini lebih baik daripada sebelumnya. Perguruan ini telah membuka beberapa jurusan dan mahasiswa yang menjanjikan. Dalam perkembangan terkini Universitas Muhammadiyah Sorong ada 6 Fakultas, 12 Program Studi, 3850 orang mahasiswa, dan 123 orang dosen.

Panti Asuhan Putra mengalami stagnasi. Kini jumlah anak asuhnya tidak ada, keadaan ini tidak pernah terjadi sejak awal keberadaannya. Walaupun yang tersisa hanya pengasuh saja. Hal ini dipengaruhi oleh beberapa faktor, pertama, panti tidak punya pengasuh yang mumpuni, kedua, anak-anak yang ingin ditampung tidak ada. Ketiga, para pengurus tidak kompak mengolah panti. Sehingga tidak heran keadaan panti putra saat ini sangat memperihatinkan. Dampaknya, ada ketidakpercayaan masyarakat dan pemerintah bila hal ini berlarut-larut. Namun untuk kedepannya panti asuhan putra akan terfokus ke Tafidzul Qur'an. Adapun panti asuhan putri dalam perkembangan terkini mempunyai 1 orang pengasuh dan 20 orang anak asuh. 


\section{Kesimpulan}

Kurangnya kerja sama yang baik antara Pimpinan Daerah Muhammadiyah dengan pengelola amal usaha Muhammadiyah, baik di bidang pendidikan maupun dibidang social menyebabkan Lembaga binaan baik di bidang pendidikan dan social menjadi tantangan yang harus segera dibenahi kedepn. Begitu juga dengan lemahnya kontrol dari Pimpinan Daerah Muhammadiyah Kota Sorong terhadap amal usahanya dan tidak berfungsinya secara maksimal majelis-majelis, organisasi otonom dan lembaga yang ada di Pimpinan Daerah Muhammadiyah Kota Sorong sangat mempengaruhi pergerakan dan perkembangan Dakwah Bil hal yang dilakukan Muhammadiyah.

Hendaknya semua pihak baik Pimpinan Daerah Muhammadiyah maupun pengelola amal usaha Muhammadiyah kedepan agar menyatukan persepsi dalam membangun dan mengembangkan amal usaha Muhammadiyah kedepan. Majelis-majelis, organisasi otonom, dan lembaga yang ada harus difungsikan sebagaimana mestinya, dan juga harus ada kerja sama yang baik diantara jenjang pendidikan untuk memajukan amal usaha di bidang pendidikan dan bidang sosial Muhammadiyah secara bersama-sama. Warga Muhammadiyah selayaknya juga harus mendukung secara kompak di dalam membantu mengembangkan lembaga pendidikannya kedepan.

\section{DAFTAR PUSTAKA}

Ahmad, H. Adjis. 2010. Muhammadiyah dan Kaderisasi, dalam Refleksi Satu Abad Muhammadiyah, PWM B-Press, Yogyarkat.

Amir, Samsul Munir. 2009. Ilmu Dakwah, Amzah, Jakarta.

Asmara, Adi. 2010. Sejarah dan Realita Pendidikan Muhammadiyah, Pustaka Offset, Yogyakarta.

Departemen Pendidikan Republik Indonesia. 2007. Kamus Besar bahasa Indonesia, Edisi ke-3, Balai Pustaka, Jakarta.

Mas, Subhan. 2005. Muhammadiyah Pintu Gerbang Protestanisme Islam, Al-Hikmah, Mojokerto.

Muhammadiyah, MPK PP. 2007. Sistem Pengkaderan Muhammadiyah, Yogyakarta.

Hambali, Hamdan. 2006. Ideologi dan Strategi Muhammadiyah, Suara Muhammadiyah, Yogyakarta.

Nashir, Haedar. 2010. Manhaj Gerakan Muhammadiyah, Ideologi, Khittah, dan Langkah, Suara Muhammadiyah, Yogyakarta.

Tim penyusun dan Penerbitan. 2005. Profil Pimpinan Pusat Muhammadiyah, Yogyakarta.

Depertemen Agama Republik Indonesia. 2006. Al-Qur'an tajwit dan terjemah, Maghfirah Pustaka, Jakarta.

Setiawan, Nur Kholis dan Djaka Soetapa. 2010. Meniti Kalam Kerukunan, BPK Gunung Mulia, Jakarta.

Suyuthie, Hasymi. 2010. Refleksi Satu Abad Muhammadiyah, PWM B-Press.

Tim Penyusun dan Penerbit Profil Muhammadiyah. 2010. Pimpinan Pusat Muhammadiyah, Yogyakarta.

Pimpinan Pusat Muhammadiyah. 2000. Pedoman Hidup Islami Warga Muhammadiyah, Suara Muhammadiyah, Yogyakarta. 
Pimpinan Pusat Muhammadiyah. 2007. Anggaran Dasar dan Anggaran Rumah tangga Muhammadiyah, Suara Muhammadiyah, Yogyakarta.

Baroni. 2006. Prinsip-prinsip Muhammadiyah, Citra Mentari, Malang.

Arifin, Fuad. 2000. Ke-Muhammadiyahan, Pustaka SM, Yokyakarta.

Azhar, Muhammad. 2005. Posmodernisme Muhammadiyah, Suara Muhammadiyah, Yogyakarta. 